\title{
An Emerging Relationship: China and Aung San Suu Kyi
}

\author{
Bai Xuefeng \\ Xiamen University Fujian, China 316005 \\ bxuefeng@xmu.edu.cn
}

\begin{abstract}
This paper provides a general review of the impressions, assessments and interactions between China and Aung San Suu Kyi (ASSK) from the earlier years of her confinement to the landmark victory of her party in the election into the new Myanmar government. With the changed political landscape and fresh domestic development in Myanmar, the role of ASSK in China and Myanmar relations assumes more importance and will shape both the direction and arrangements of the diplomatic relations between the two countries in the future. Based on the release of the U.S. diplomatic cables and other publically available materials, this paper reviews the development of the emerging relationship between China and Myanmar from the perspective of ASSK as an indispensable political figure. The analysis of the paper offers observations that provide context and insights into the important political dynamic between the two closely related neighbours.
\end{abstract}

Keywords-Burma; Myanmar; Aung San Suu Kyi; China; Foreign Relations

\section{INTRODUCTION}

Dramatic changes to the political landscape of Myanmar came about in the 2015 election when Aung San Suu Kyi (ASSK) and her party, the National League for Democracy (NLD) won by a landslide and ASSK assumed key government positions both as the state counselor and Minister of Foreign Affairs. Given the numerous political changes that have transpired internally within Myanmar as well as the observable changes in relations with China it is prudent to investigate how her presence impacts China-Myanmar relations.

\section{CHINA'S INITIAL ASSESSMENT OF MYANMAR'S SITUATION}

\section{A. The junta's psychology}

The junta faced a dilemma. On the one hand the junta could release ASSK and of necessity, "voluntarily step down and face heavy retribution." On the other hand the junta could "remain in power by violently clamping down on the population," although as the U.S. diplomatic cable notes the military did not want to implement either of these options [1]. The military junta could not release ASSK because it feared the tidal wave of consequences that would occur. The then China's Vice Foreign Minister commented that most senior Burmese leaders feared ASSK and were unlikely to release her while also contending that their vision for national reconciliation did not include ASSK [2]. Ultimately, the junta's fears naturally inhibited political dialogue within Myanmar. However as the Chinese ambassador to Myanmar astutely observed as early as 2008 if the senior leaders could be offered assurances that they would not "lose their lives" and could keep their economic interests, they might be more amenable to ceding power gradually [3], which is what ultimately transpired.

\section{B. Junta was supposed to be the key to maintain regional stability}

While China expressed concern about assurances for the senior leaders of the junta, it believed that the junta had the ability to retain its power and ensure the stability of Myanmar and the region, even though China knew the junta did not have the support of the people and had failed to achieve national reconciliation and economic development. This position was confirmed in October, 2009 when the Chinese diplomat said that despite the problems, the regime could not be replaced, and long-term stability and development would take time, especially given the complexity of the situation in Burma [4].

The matter of stability was important to both the junta and China, although they held different views of the issue. For the junta, stability meant maintaining their interests as well as holding on to power. China, however, was concerned about the repercussions that would follow if the junta lost its power, including creating unrest and destabilizing the border. MFA's Asian Affairs Deputy Director General said that the PRC worried that if the junta was suddenly displaced and Burma became democratic no one could be sure of the outcome. $\mathrm{He}$ also argued that the military was the only force that could keep Burma stable. A sudden move to democracy in Myanmar, according to Beijing, could lead to the disintegration of Burma or the collapse of its economy, due to the inevitable economic sanctions that would follow, which would destabilize the region and precipitate a flow of refugees [5].

Even though China insisted that Myanmar should decide its own political future, Beijing did not unconditionally support Burma or necessarily like its politics. A meeting with the US Assistant Secretary Christopher Hill and the then Vice Foreign Minister confirmed China's support for Burma as its neighbour and stressed that, while Beijing expected the military regime to retain its power in the foreseeable future, China's position was not to be interpreted to mean that Beijing approved of Myanmar's policies. The Chinese diplomat also shared his personal experience with his US counterpart about 
his visit to Myanmar in 2005; he complained that his Burmese counterpart read from only one page of talking points and constantly repeated himself during 12 hours of talks [6].

\section{ASSK was relevant but not a crucial factor}

Initially, Beijing believed that ASSK and her party played a limited role in Myanmar because the military junta was well able to hold on to power thereby limiting any unsavoury retribution that might transpire should they lose their political clout and overarching rule. Although China certainly recognized ASSK as a relevant party while also reiterating its support for national reconciliation and encouraging all relevant parties in Burma to realize reconciliation through dialogue [7], China initially, unlike the US, considered ASSK a non-critical element in the process of national conciliation and simply another of the many issues facing Myanmar [8]. As Zhao noted in 2006, China did not believe ASSK's plight should dominate the international community's engagement with Burma and that all parties would be better served by focusing on issues such as counternarcotics, trafficking in persons, public health and infectious disease issues [9].

Further, Chinese diplomat also expressed concerns about ASSK's skills and ability to govern the country. China's Ministry of Foreign Affairs official was reported to have said that even if ASSK were in power she would not be able to lead the country effectively given the complexity of the problems Burma faced [10]. This opinion may have resulted in part because ASSK was thought to lack insight into economic issues, although her leadership eventually attracted the kind of economic talent that could assist Burma [11]. Therefore it can be inferred that even though ASSK continued to be relevant in Myanmar, she was initially not considered to be able to play a significant role in China-Myanmar relations.

\section{COMPARISON OF CHINA AND US ATTITUDES TOWARD ASSK}

The US has been holding ASSK in high regard noting that she had played a vital role in shaping US policy in a manner rarely seen in prior international relations with any country. On the other hand, China originally considered ASSK minimally relevant and expressed confidence in the ruling junta to retain power and maintain stability. China did not foresee that the junta would ultimately quietly withdraw from power, ease its opposition to ASSK and the NLD and then negotiate a rapid rapprochement with the United States. Shortly after the transition of power to the quasi-civilian government in 2011, China was further caught off guard when the Burmese government announced the suspension of the Myitsone Dam Project which was intended to create a hydroelectric development that would have exported $90 \%$ of the resulting electricity to China.

Clearly, China and the US held different views of ASSK and her impact on foreign relations. The US policy toward Myanmar focused on the lack of the junta's legitimacy. The US held that while the junta lacked legitimacy but maintained a total grip on power, the NLD, ASSK and other opposition groups had legitimacy but no access to power [12]. In contrast, China did not place ASSK at the center of Myanmar-China relations, but rather believed that the junta was central to
China's policy since they were most likely to retain power and thereby offset the destabilization that would occur within Burma if they were displaced.

Later, China drastically changed its attitude toward ASSK and her role was eventually recognized as centrally important to Chinese-Myanmar relations. This change was particularly reflected in 2015 when ASSK was invited to China to meet with General Secretary of the Communist Party of China and President Xi Jinping.

\section{ASSK'S ATTITUDE AND RESPONSES TOWARD CHINA}

Having considered the perspectives of both China and the US toward ASSK, examining the reverse side of the relationship, that is ASSK's attitude and response to China will also prove worthwhile. Despite the initial lack of substantive interaction between China and ASSK, ASSK has continues to respond pragmatically toward China, recognizing its importance as a neighbor and seeking to establish a mutually beneficial relationship.

\section{A. China is an immense neighbor and a reality}

Fundamentally, ASSK recognizes China as a geographic neighbor whose presence and influence is considerable; this is nothing short of reality. Consequently, ASSK holds that China should be treated respectfully like a neighbor while also seeking to negotiate mutually beneficial and peaceful relations.

During the years of her detention and house arrest, ASSK had little opportunity to travel and limited interaction with China. However, even during this time ASSK's opinion of China was not completely unknown. For example, when ASSK met with the UN Special Envoy, Ibrahim Gambari, she conveyed to Beijing via Gambari that she would not seek to politically leverage the occasion of the 2008 Beijing Olympics [13]. Her assurance that she would not seek to politically leverage the 2008 Beijing Olympics laid a solid foundation for her future friendly interactions with China.

ASSK's attitude toward China was no secret to the US government as was confirmed by a classified cable report from the US embassy in Yangon. The cable says that the political opposition, including ASSK and her major party members, "has made clear to us that they realize their immense Chinese neighbor is a geo-political reality that must be managed and cannot just be rebuffed or ignored" [14].

\section{B. ASSK's vision of China as a good neighbor}

Although ASSK clearly enunciated her desire to have a peaceful relationship with China, she also had a clear sense of what such a relationship entailed. This vision was articulated immediately after her release from seven years' house arrest on 13 Nov 2010 when ASSK went to the NLD headquarters where she addressed a wide range of issues concerning the past, present, and future of Burma.

As questions were posed during her initial remarks, one questioner asked her to comment on China "stealing Myanmar's resources." ASSK replied, "I would not like to use the word 'stolen'. I think that there are many of our resources that should not have been sold unadvisedly." She went on to 
advise that Burma take greater care in utilizing its resources. Still further, she emphasized that she did not regard China as an enemy and noted that Burma should work hard to be good neighbors with China [15]. Again, in another interview with the South China Morning Post in 2011, one year after her release, ASSK reiterated her hope that China would be Myanmar's friend despite the "bumps and kinks" attending the relationship. She also emphasized that her primary concern was to ensure that Myanmar and its people's best interest was paramount [16]. These remarks essentially summarize ASSK's policy toward China both right after her release from house arrest and six years later when she became Myanmar's Foreign Minister.

\section{ASSK's call for suspension of the Myitsone Dam}

The first real test of how ASSK implemented her notion of being both a good neighbor with China and also, at the same time, looking after Myanmar's welfare, came about as a result of the issues surrounding the suspension of Myitsone Dam project, which was initiated on March 26, 2009 in an agreement signed by representatives of SPDC and a high level Chinese delegation. This notable day brought about four separate agreements including Myanmar-China Oil and Gas Pipelines, the Development of Hydropower Resources in Myanmar, Economic and Technical Cooperation agreements and an MOU regarding Buyer's Credit for Constructions Projects. However, after investigations including a briefing from the International Rivers Organization and a report by Kachin Development Networking Group (KDNG) that cited the environmental and social impacts of the Myitsone Dam project, many opposed the 3.6 billion US dollar mega project.

ASSK agreed with the opponents of the dam project and in concert with NLD called for the project to be suspended. On August 11, 2011 ASSK issued a statement that outlined her concerns. She noted that the great river was under threat and urged that "in the interests of both national and international harmony, concerned parties should reassess the scheme and cooperate to find solutions that would prevent undesirable consequences" [17]. In this way, she exerted her influence for the good of Myanmar while also seeking a mutually beneficial relationship with China. Although ASSK did not indicate opposition to China's investment in her country, she did place Myanmar's interests above all other concerns, which represents a fundamental stance in her relationship with China.

\section{ASSK's handling of the Letpadaung Copper Mine investigation}

This same stance was taken when ASSK handled the crisis surrounding the Letpadaung Copper Mine project which was established as a joint venture between the Union of Myanmar Economic Holdings Company (UMEHL), the largest stateowned enterprise controlled by the Burmese military, and Wanbao Mining. As the Chairperson of the Investigative Commission of the Letpadaung Copper Mine in 2014, ASSK, along with the committee issued a report which backed the continuation of the project on the condition that it implemented the recommended revisions and changes of the terms outlined by the reviewers.

In particularly, the Commission held that Wanbao had reduced payments to local farmers by unfairly manipulating the compensation process; the group required Wanbao to increase payments to the farmers. They also found that the houses Wanbao provided for the displaced residents were sub-standard and of poor quality which was another issue that the committee required Wanbao to address. In short, the Commission called for a re-negotiation of the terms of compensation for the farmers before the Letpadaung Copper Mine could move forward. Furthermore, even though the Commission did not recommend that the Project's expansion be halted, the Report stated that the mine lacked strong environmental protection measures and had been developed without environmental, social or heath impact assessments having taken place. The project also failed to have an environmental management plan in place. The Commission, therefore, required that these deficiencies be corrected. They also held that if revision of terms did, indeed, transpire which appropriately addressed the issues that had been raised the project could move forward. Interestingly, the Report also acknowledged that the Project would not necessarily create jobs for local residents [18].

Although ASSK has enjoyed strong US support and has maintained connections with other western countries, this does not appear to play a major role in her emerging relationship with China, given her attitude and stance toward China and the current political dynamics between China and Myanmar. Although ASSK's ideology is pro-western, in terms of her foreign policy with China, she will not lean toward the West but rather consider Myanmar's national interests as the guiding principle in her subsequent relations with China. Obviously, it is Myanmar's national interests to maintain good terms with China. 


\section{CONCLUSION}

The potential for a strong alliance and mutually beneficial relationship between China and Myanmar is unlimited if both nations are able to negotiate appropriate terms that consider the interests of both. For Myanmar formulating its own plans that give priority to its national interests while also inviting China to help revitalize its economy should prove highly advantageous. Similarly, China will also benefit as it deepens and extends its relationship with Myanmar, particularly in view of Burma's participation in the One Belt One Road national strategic initiative initiated by the Chinese President.

Although the fate of the Myitsone Dam is still undecided, China's economic presence in Myanmar can be diverted to the infrastructure and manufacturing sectors. For example, in December 2015, a consortium of six foreign companies, led by China's CITIC, won the bid for building a deep sea port on the Bay of Bengal while another group signed a contract to develop an industrial area in Myanmar's newly planned special economic zone (SEZ) in Kyaukphyu, in the western State of Rakhine.

The symbiotic relationship that appears to be developing between China and Myanmar will no doubt bring concrete benefits to the local people of Burma as well as the larger national economy thereby dampening the voices of opposition and the claim that ASSK is too soft on China. At the same time, although it may take time for China and investors to realize the benefits of its long term presence and economic investment in Myanmar, together with emphasis on public service and corporate social responsibility, in the end, economic and political pay-offs are likely to accrue. If proper terms are negotiated and benefits are fairly shared, both countries can turn the reality of being geographical neighbors into becoming mutually beneficial neighbors.

\section{REFERENCES}

[1] "Prc Mfa Official Calls for Patience on Burma." 2008. Wikileaks Public Library of US Diplomacy 08BEIJING3612_a. China Beijing.

[2] “A/S Hill's May 25 Working Lunch with Vfm Wu Dawei." 2006 Wikileaks Public Library of US Diplomacy 06BEIJING10909_a. China Beijing.

[3] "Chinese Losing Patience with Burma." 2008. Wikileaks Public Library of US Diplomacy 08RANGOON44_a. Burma Yangon.

[4] "Prc/Burma: A/S Campbell's Meeting with Asian Affairs Dg Yang Yanyi." 2009. Wikileaks Public Library of US Diplomacy 09BEIJING2868_a. China Beijing.

[5] "Burma Consultations with Prc." 2006. Wikileaks Public Library of US Diplomacy 06BEIJING2776_a. China Beijing

[6] “A/S Hill's May 25 Working Lunch with Vfm Wu Dawei." 2006. Wikileaks Public Library of US Diplomacy 06BEIJING10909_a. China Beijing.

[7] “Afm He Yafei Reviews China's Key Issues for the Secretary's Visit." 2008. Wikileaks Public Library of US Diplomacy 08BEIJING659_a. China Beijing.

[8] "China to Consider Formal Unsc Briefing on Burma, Opposes 'Too Much' Pressure on Rangoon.” 2007. Wikileaks Public Library of US Diplomacy 07BEIJING5918_a. China Beijing.

[9] "Burma Consultations with Prc." 2006. Wikileaks Public Library of US Diplomacy 06BEIJING2776_a. China Beijing.

[10] "Das Christensen Discusses Burma with Mfa Asian Affairs Dg Hu Zhengyue.” 2007. Wikileaks Public Library of US Diplomacy 07BEIJING888_a. China Beijing.

[11] "Prc Mfa Official Calls for Patience on Burma." 2008. Wikileaks Public Library of US Diplomacy 08BEIJING3612_a. China Beijing.

[12] “Prc/Burma: A/S Campbell's Meeting with Asian Affairs Dg Yang Yanyi." 2009. Wikileaks Public Library of US Diplomacy 09BEIJING2868_a. China Beijing.

[13] "Gambari to Push Dialogue in Burma; China Still Supports "Roadmap."' 2007. Wikileaks Public Library of US Diplomacy 07BEIJING6851_a. China Beijing.

[14] "Crouching Tiger, Hidden Economy: Burma-China Economic Relations." 2010. Wikileaks Public Library of US Diplomacy 10RANGOON102_a. Burma Yangon.

[15] Aung San Suu Kyi. 2010. "Transcript of Aung San Suu Kyi’s Press Conference." Press Briefing. NLD Headqurters Yangon, Myanmar. https://www.article19.org/resources.php/resource/1657/en/transcript-ofaung-san-suu-kyi's-press-conference.

[16] Suu Kyi anxious to smooth "bumps" with Beijing [WWW Document], 2011. South China Morning Post. URI http://www.scmp.com/article/984828/suu-kyi-anxious-smooth-bumpsbeijing (accessed 5.16.16)

[17] Aung San Suu Kyi. 2011. "Lrrawaddy Appeal." 54-56 University Avenue Bahan Township Rangoon, August 11 http://www.burmacentredelhi.org/campaign-advocacy/statement/1004statement-of-daw-aung-san-suu-kyi-personal-appeal-to-save-theirrawaddy-river.html.

[18] The Letpadaung Taung Investigation Commission. 2013. "Letpadaung Investigation Commission Final Report." http://www.myanmaryangtse.com.mm/media-releases/135-letpadaunginvestigation-commission.html. 